\title{
LITERATUR TAFSIR BI AL MATSUR DI KALANGAN SUNNI: Tinjauan Historis dan Metodologis
}

\author{
Ali Hamdan \\ Fakultas Syariah UIN Maulana Malik Ibrahim Malang \\ Telp: 081283688918 \\ email: alihamdannasution@gmail.com
}

\begin{abstract}
This article aimed to map the literature of Quran exegesis prevailing for Sunni. There are seven literatures classified as a tafsir bi al matsur, and four of them elaborated as comparison, namely Adhwa al Bayan fi Iydhah al Quran bi al Quran of asy Syinqithi, Jami al Bayan fi Tawil al Quran of Ibnu Jarir al Thabari, Tafsir al Quran al Adzhim of Ibnu Katsir and al Dar al Mantsur fi at Tafsir bi al Matsur of Imam Suyuthi. The historical study and methodology are the main subject of this literatures research using library approach. The research show that there are some excellence and weakness of each literatures if they are viewed by methodology aspect. But according definition of al Matsur, the most valid (mutamad) literature is Adhwa al Bayan fi Iydhah al Quran bi al Quran. Whereas according to turats and seniority of writer, the most valid literature is Jami al Bayan fi Tawil al Quran. The third position is Tafsir al Quran al Adzhim, as a resume of Jami al Bayan fi Tawil al Quran. And the last position is al Dar al Mantsur fi at Tafsir bi al Matsur, because its sanad validation only pin up the closest of rawi.
\end{abstract}

Tulisan ini bertujuan memetakan literatur-literatur tafsir yang berlaku dikalangan sunni. Ada tujuh literatur yang diklasifikasi sebagai tafsir bi al matsur dan hanya empat diantaranya yang dibahas dalam tulisan ini sebagai perbandingan, yaitu: Adhwa al Bayan fi Iydhah al Quran bi al Quran karya asy Syinqithi, Jami al Bayan fi Tawil al Quran karya Ibnu Jarir al Thabari, Tafsir al Quran al Adzhim karya Ibnu Katsir dan al Dar al Mantsur fi at Tafsir bi al Matsur karya Imam Suyuthi. Kajian historis dan metodologis merupakan subjek pokok 
dalam penelitian literatur di atas yang menggunakan pendekatan kepustakaan. Hasil penelitian menunjukkan bahwa ada kelebihan dan kekurangan masingmasing literatur ditinjau dari aspek metodologis. Apabila berpegang kepada defenisi al Matsur, maka literatur yang paling valid (mutamad) adalah Adhwa al Bayan fi Iydhah al Quran bi al Quran. Kalau berdasarkan aspek turats dan senioritas penulis maka literatur yang paling valid Jami al Bayan fi Tawil al Quran. Posisi ketiga adalah Tafsir al Quran al Adzhim yang merupakan ringkasan dari kitab Jami al Bayan fi Tawil al Quran. Peringkat keempat adalah kitab al Dar al Mantsur fi at Tafsir bi al Matsur dikarenakan validasi sanad yang hanya mencantumkan rawi yang paling dekat.

Keywords: Tafsir bi al matsur, the historical study, turats

\section{Pendahuluan}

Al Quran adalah Kalamullah yang diturunkan sebagai kitab penutup kepada rasul penutup yang ummi dan ummat yang ummi, dengan lafadz-lafadz berbahasa arab. Pokok-pokok al Quran menyentuh sisi-sisi sensitif kehidupan seorang muslim yang berkaitan dengan individual, sosial, hukum, serta syariat.

Tafsir merupakan disiplin ilmu yang digunakan dalam memahami al Quran. Tafsir memiliki tempat yang tinggi dan derajat yang mulia, dan juga sebaik-baik obyek ilmu pengetahuan, dikarenakan thema dan pembahasannya berkaitan langsung dengan al Quran serta penerapannya yang berkaitan dengan aspek kehidupan manusia.

Perjalanan Tafsir sebagai suatu disiplin ilmu, yang digemari dan selalu dikaji seperti sekarang ini, terlebih dahulu mengalami sejarah yang sangat panjang, sejak Nabi SAW menerima wahyu berupa ayat-ayat al Quran melalui maikat Jibril. Dalam perjalanannya, banyak diantara ayat-ayat al Quran itu yang memerlukan penjelasan lebih dalam dan keterangan yang lebih valid dari nabi SAW, sehingga penjelasan dan keterangan tersebut dengan sendirinya menjalin komunikasi yang interaktif dan dialog yang vertikal dalam ruang lingkup keilmuan ditengah-tengah Nabi dan Shahabat. Seiring dengan berkembangnya Islam di semenanjung Arabia, Shahabat juga memiliki kewajiban untuk mengajarkan Islam dan al Quran di wilayah tersebut, sehingga Shahabat memiliki generasi penerus sebagai murid yang mewarisi ilmu dan keilmuan. Dengan demikian, dalam perjalanan Tafsir sebagai suatu disiplin ilmu, semakin berkembang dan hadir lebih dekat di tengah-tengah akademik umat Islam. Khazanah keilmuan dan maha karya dari akademisi-akademisi Shahabat serta 
tabiin dan generasi penerus setelah abad merekalah yang diwarisi oleh umat Islam saat ini berupa kitab-kitab turats yang sangat banyak dan memenuhi perpustakaan-perpustakaan di negara-negara muslim dan juga barat. Selain itu, kitab-kitab turats tersebut juga menjadi bahan kajian dan perdebatan di kalangan akademisi dan juga ilmuan-ilmuan muslim.

Tafsir sebagai disiplin ilmu telah berkembang sedemikian rupa yang ditemukan dalam bentuk karya dan essay ilmiah, baik yang sudah dicetak maupun yang masih tertulis dan tersimpan rapi dalam bentuk makhthuthat di perpustakaan-perpustakaan Islam. Tafsir sebagai suatu disiplin ilmu telah terurai pada masa nabi seiring dengan diturunkannya al Quran dikarenakan beliaulah yang berhaq menjelaskan. Suatu hal yang semestinya, apabila Nabi SAW dapat memahami keseluruhan al Quran dengan detail dan terperinci, karena hal itu telah tergaransi (QS al Qiyaamah: 17-19).

Tafsir bi al Matsur merupakan metode menafsirkan al Quran dengan menggunakan al Quran itu sendiri, atau hadits Nabi SAW yang berfungsi menerangkan ayat-ayat al Quran, atau yang diriwayatkan Shahabat dari Nabi SAW, atau yang di riwayakan tabiin dari Shahabat (al Qaththan, 2000: 358). Metode al Matsur ini terimplikasi dalam kitab-kitab besar karya ulama dan ilmuan dari abad pertama sampai dengan masa sekarang serta menjadi rujukan utama Tafsir bi al Matsur di universitas negara-negara arab, diantaranya: Jami al Bayan fi Tawil al Quran karya Ibnu Jarir ath Thabari (w. 310 H ), Bahrul Ulum karya Abu al Laits as Samarqand (w. 375 H ), Tafsir al Quran al Adzim karya Abu al Fida Ibnu Katsir (w. 399 H ), ad Dar al Mantsur fi at Tafsir bi al Matsur karya Jalaludin as Suyuthi (w. 911 H), Irsyad al Aqli as Salìm ila Mizaya al Kitab al Karim karya Abu Suud al Ammadi, dan Adhwa al-Bayan fì Iydhah al Quran bi al Quran karya Muhammad Amin asy Syinqithi (w. 1393 H/1973 M ).

Pengertian Ahlu al Sunnah wa al Jamaah adalah: "golongan yang senantiasa mengikuti jalan hidup Rasulullah SAW serta jalan hidup Sahabatnya". Dan juga bisa diartikan sebagai "golongan yang berpegang teguh pada Sunnah Rasul dan Sunnah Sahabat" (Nasir, 2010: 187). Istilah Sunni muncul pada masa kekhalifahan Abasyiah dijabat Abu Jafar al Mansur (137-159 H/ 754-755 M). Booming sunni terjadi dimulai saat Imam Ahmad bin Hanbal (720-855 M) tidak mengakui al Quran sebagai makhluk dan salah satu ideologi negara. Masa kristalisasi ajaran dan sebutan Sunni itu terjadi dengan munculnya Abu Hasan al Asyari (260-364 H/ 873-935 M) dan Abu Mansur al Maturidi (944 M) membawa ajaran dan faham aqidah baru yang menyalahi ideologi negara saat itu yang dikenal dengan istilah Ahlu Sunnah wa al Jamaah. Masa 
keemasan dan berkembang faham sunni terjadi saat Khalifah al Mutawaqqil (847-861 M) menjabat khalifah Abbasyiah, yang akhirnya mengakui faham Sunni sebagai ideologi negara.

\section{Tafsir bi al Matsur dalam Tinjauan Historis}

Sumber tafsir yang berbeda melahirkan sistematika dan metode penafsiran yang berbeda pula. Kitab-kitab Tafsir karya ilmuan-ilmuan terdahulu dan sekarang memiliki corak yang berbeda apabila ditinjau dari berbagai sudut pandang. Hal itu sangat logis apabila memperhatikan aktivitas penulisan dan kodifikasi tafsir serta pencantuman sumber dari waktu kewaktu tidaklah sama. Konsekuensinya, kitab-kitab tafsir yang dihasilkan memiliki keragaman, baik yang menyangkut kualitas, kuantitas maupun validitasnya.

Shahabat memiliki tingkat kecerdasan, keilmuan dan inteligensi yang berbeda dalam memahami kandungan dan tafsir ayat-ayat al Quran dengan baik, utamanya yang berkaitan dengan kosa kata. Linguistic merupakan indikator yang menentukan dalam memahami al Quran, dan hanya sebagian Shahabat saja yang dapat memahami kandungan al Quran dan itupun terbatas dalam hal-hal yang berkaitan dengan zhahir ayat. Ayat-ayat al Quran yang multi interpretasi, belum dapat difahami sebagian Shahabat dengan baik serta masih membutuhkan penelitian, opini individu, atau memperhatikan penjelasan nabi SAW. Hal sebaliknya di ungkapkan Ibnu Khaldun dalam "muqaddimahnya" seperti yang dikutip oleh Husain adz Dzahaby: "al Quran diturunkan berbahasa arab dengan dialektika arab, secara alami mereka dapat memahami maknamaknanya dalam bentuk kosakata serta susunannya" (adz Dzahabi, tt: 29). Realitanya sungguh berbeda, walaupun al Quran itu berbahasa arab, hal itu bukanlah jaminan bahwa orang arab bisa mengetahui dan memahaminya secara sempurna dan terperinci, utamanya yang menyangkut kosa kata dan juga istilah. Makna sebagaian kosa kata dalam ayat al Quran itu tidak difahami sebagian Shahabat. Seperti di riwayatkan, Umar bin al-Khaththab pernah

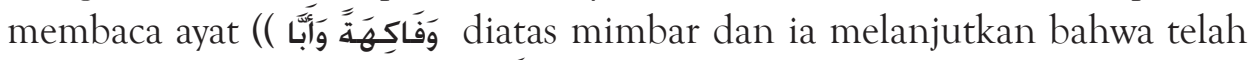
memahami maksud dari kata (فَاكَهَ) akan tetapi belum memahami maksud kata ( أبََّا ). Hal ini di jelaskan kemudian oleh Shahabat yang lain, bahwa maksudnya adalah at takalluf (al Khurasani, $1417 \mathrm{H}$ : 170). Contoh kedua, riwayat Ibnu Abbas berkata: "aku tidak mengetahui apa maksud dari ( فَاطِرِ sehingga dua orang araby yang berseteru mendatangiku disebuah wadi, salah satunya berkata ( أنا فطرتها ), dan yang lain menyahut (أنا ابتدأتها ) (asy Syafi>i, $1370 \mathrm{H}:$ 73). 
Memperhatikan dua riwayat diatas, apabila Umar bin Khaththab belum memahami makna dari ( ), di sisi lain Ibnu Abbas mufassir al Quran belum valid memahami makna kata (فَاطِر ) kecuali setelah mendengar dari Shahabat yang lain, sedangkan Umar dan Ibnu Abbas merupakan ilmuan dan cendekiawan Shahabat dan selalu bersama Nabi SAW saat itu, bagaimana dengan tingkat kecerdasan dan keilmuan Shahabat-Shahabat yang lain? Dapat di simpulkan, Shahabat memiliki kecerdasan dan tingkat keilmuan yang berbeda dalam menafsirkan al Quran, walaupun disatu sisi memiliki tingkatan yang sama dalam memahami dikarenakan memiliki bahasa yang sama. Selain itu, kebersamaan dengan Nabi juga faktor penentu, selalu bersama Nabi tentunya lebih sering menyaksikan penjelasan dan keterangan dari Nabi, dibandingkan dengan Shahabat yang jarang bersama Nabi.

Shahabat-Shahabat Nabi yang dikenal memiliki kecerdasan dan keilmuan dalam bidang tafsir adalah Khulafa ar Rasyidin yang empat, Abdullah bin Masud, Abdullah bin Abbas, Ubay bin Kaab, Zaid bin as Tsabit, Abu Musa al Asyari dan Abdullah bin Zubair (as Suyuthi, 1394 H/1974 M: 233). Selain Shahabat di atas, masih banyak Shahabat yang lain yang dikenal sebagai mufassir walaupun pendapat dan opini individu mereka tidak terlalu banyak ditemukan. Seperti Anas bin Malik, Abi Hurairah, Abdillah bin Umar, Jabir bin Abdillah, Abdilah bin Amru bin Ash dan Aisyah r.a (adz Dzahabi, tt: 49).

Sumber primer (al Mashadir al Ashliyyah) dalam menafsirkan al Quran pada periode Shahabat ini adalah al Quran al Karim berdasarkan ayat-ayat yang lain, Penjelasan Nabi SAW yang dikenal dengan hadits, Riwayat ahlu kitab, Ijtihad dan Isthinbat.

Seiring dengan meluasnya wilayah kekuasaan Islam pada masa Khulafa ar Raysidin, maka pada pertengahan abad ke I H banyak Shahabat yang bermigrasi kewilayah-wilayah Islam yang baru ditaklukkan untuk mengembangkan Islam dan segala aspek keilmuannya. Bahkan diantara Shahabat-Shahabat tersebut banyak yang menempati jabatan exekutif seperti Wali, Qadi, Menteri dan banyak pula yang sekedar berprofesi sebagai akademisi. Akademisi-akademisi sahabat kemudian mengajarkan ilmu pengetahuan yang mereka peroleh dari Nabi SAW utamanya di bidang tafsir. Maka terlahirlah generasi Tabiin dari tangan mereka dengan meriwayatkan apa yang mereka ajarkan, sehingga dikenal di wilayah-wilayah yang baru ini dengan sebutan madrasah ilmiyah, Shahabat sebagai guru dan tabiin sebagai muridnya. Diantara madrasah ini ada yang dikenal dengan sebutan madrasah tafsir yaitu tabiin berguru kepada mufassir Shahabat yang kompeten dan melahirkan generasi tabiin yang ilmuan 
di bidang tafsir. Diantara sekian madrasah Tafsir yang sangat terkenal ada tiga, yaitu madrasah Tafsir di Makkah, Madinah dan Iraq. Seperti yang disebutkan Ibnu Taimiyah: "Adapun tentang Tafsir, maka tabiin yang paling menguasai adalah teman-teman Ibnu Abbas sepert Mujahid, Atha bin Abi Rabah, Ikrimah Maula Ibnu Abbas dan Thaus. Kemudian Ahlu Kufah yaitu murid-murid Ibnu Masud seperti Qatadah as Sadusi. Kemudian Ahlu Madinah yaitu murid-murid Zaid bin Aslam seperti Abd Rahman bin Zaid dan Abdullah bin Wahab (al Haji: 1427 H/2007M).

Al Mashadir al Ashliyah (sumber primer) tafsir pada periode tabiin ini adalah al Quran, Riwayat Shahabat yang bersumber dari Nabi SAW, Riwayat tabiin, Riwayat ahlu kitab yang berasal dari kitab-kitab mereka, Ijtihad dan Istinbath (adz Dzahabi, tt: 79). Perlu di cermati dalam periode ini dengan terakomodasinya israiliyat dan nashraniyat dalam tafsir sebagai implikasi dan dampak terakomodasinya riwayat-riwayat ahlu kitab sebagai sumber Tafsir. Dan hal itu banyak ditemukan didalam kitab-kitab Tafsir bi al Matsur seperti dalam kitab Tafsir al Quran al Adzimnya Ibnu Katsir.

Proses kodifikasi tafsir dimulai Pada abad ke II H dengan susunan tafsir menjadi salah satu bab dari susunan hadits. Dalam periode ini juga tafsir belum dikodifikasi khusus dalam lingkup surat sesuai dengan susunannya. Proses kodifikasi ini terlaksana berkat kesadaran, tanggung jawab dan fenomena ilmiah ilmuan-ilmuan muslim yang berkunjung ke wilayah-wilayah Islam yang baru ditaklukkan untuk mengumpulkan dan menyusun hadits-hadits Nabi SAW, dan kemudian meriwayatkan tafsir yang dinisbahkan kepada Nabi, Shahabat dan tabiin, seperti yang di lakukan oleh Yazid bin Harun as Sulami (w. 117 H ), Syubah bin al Hajjaj (w. 160 H ), Waki bin al Jarrah (w. 197 H ), Sufyan bin Uyainah ( w. 198 H ) dan Ilmuan-ilmuan yang lain (az Zarqani, 1367 H: 28 ).

Ilmuan-ilmuan muslim memulai penyusunan tafsir sebagai suatu bidang keilmuan yang terpisah dari bidang hadits pada abad ke III dan ke IV H, menafsirkan ayat-ayat al Quran surat demi surat sesuai dengan susunannya dan tersusun dalam satu kitab, Seperti yang dilakukan oleh Ibnu Majah ( w. $273 \mathrm{H}$ ), Ibnu Jarir ath Thabari (w. 310 H ), Ibnu Abi Hatim (w. 327 H ), dan imam Hakim (w. 405 H ). Dapat diperhatikan tafsir yang disusun oleh ilmuan-ilmuan besar diatas tersusun dengan metode al Matsur yang terfokus dalam periwayatkan dari Nabi SAW, Shahabat dan tabiin.

Ekspektasi penyusunan tafsir melebihi perkiraan pada abad ke V H dan masih dalam lingkup metode al Matsur. Hanya saja muncul beberapa 
sistematika dan corak baru dalam penyusunannya seperti: Pertama, penyusunan yang makin beragam, kedua meringkas sanad dengan hanya mencantumkan rawi yang paling dekat, ketiga mengutip pendapat mufassir tanpa pencantuman nama, keempat terakomodasinya al Wad'u, kelima memandang isi kitab tafsir selalu benar, dan keenam semakin berkembangnya israiliyat.

Dengan demikian, melihat fenomena yang terjadi dalam beberapa periode perkembangan Tafsir sampai ke periode sekarang ini dapat ditemukan fakta empiris, pertama, sumber Primer Tafsir bi al Matsur adalah al Quran, hadits Nabi SAW, Ijtihad Shahabat dan juga Ijtihad tabiin, dan bila mengacu kepada sumber primer diatas, maka akan ditemukan kitab-kitab tafsir yang turats dan kontemporer yang memakai sumber tafsir seperti sumber primer diatas, kedua pada umumnya kitab-kitab tafsir itu banyak corak dan ragamnya bila ditinjau dari sisi metodologi. Hal itu mengingat banyaknya firqah dan aliran dalam Islam yang juga memiliki kitab tafsir acuan untuk dikonsumsi individu dan kelompok, maupun untuk umat Islam secara umum.

\section{Tafsir bi al matsur dalam Tinjauan Metodologis}

A. Adwa al Bayan fi Iydhah al Quran bi al Quran

1. Riwayat Hidup Penyusun

Kitab ini di susun oleh mufassir besar Muhammad Amin Mukhtar bin Muhammad al Mukhtar al Jakni asy Syinqithi. Lahir tahun $1325 \mathrm{H}$ di desa Tanba, Provinsi Shinqithi yang masuk dalam teritorial Republik Islam Mauritania (al Rumi, 1986: 123). Asy Syinqithi ditinggal wafat oleh ayahnya dalam usia balita sehingga ia tumbuh dalam asuhan ibu dan juga famili dekatnya. Perjalanan Ilmiahnya dilalui dengan belajar kepada sanak saudara yang mengasuh seperti khatam hafalan al Quran dalam bimbingan pakcik dalam usianya yang masih sepuluh tahun. Asy Syinqithi kecil juga mempelajari model tulisan Mushaf Usmani kepada sepupunya, serta mempelajari Sastra Arab dibimbing isteri pakciknya. Fiqh Imam Malik dan Alfiah Ibnu Malik dalam bidang Nahwu juga menjadi materi lanjutan yang dipelajarinya. Bisa dikatakan bahwa rumah pakciknya merupakan sekolah non formal pertama yang diikuti dan memberikan dampak besar bagi perkembangan keilmuannya dimasa selanjutnya. Selanjutnya Syaikh asy Syinqithi kecil belajar ilmu pengetahuan yang berbeda dan bermacam-macam kebeberapa Syaikh lokal yang masih termasuk klan Jakni. Setelah dewasa beliau menunaikan Ibadah Haji dan kemudian berkomunikasi dengan ulama-ulama Hijaz dengan cara menghadiri halaqah-halaqah di Masjidil Haram dan Nabawi. Komunikasi 
yang intensif membuatnya mengagumi Ulama Hijaz sehingga ia berniat menetap dan melanjutkan perjalanan ilmiahnya di negara itu. Asy Syinqithi lalu menyibukkan diri dengan mempelajari kitab-kitab Ibnu Taimiah, Ibnu al Qayyim serta karya-karya Muhammad bin Abd. Wahab.

Setelah belajar dan menuntut ilmu dalam berbagai disiplin dan cabangcabangnya, Raja Abd Aziz kemudian mengijinkannya untuk Mengajar di halaqah Masjid Nabawi. Dari sanalah karirnya sebagai seorang khodimul ilmi mencapai puncaknya sehingga ilmu dan keilmuannya terdengar di seantero kota Madinah lalu Kerajaan Arab Saudi. Kesehariannya hanya berkutat dengan al Quran dan juga ilmu-ilmunya, dan setiap hari ia mengajarkan al Quran dan Tafsirnya di Mesjidil Haram dari selesai shalat Asar hingga masuk Waktu shalat Isya. Pada tahun $1371 \mathrm{H}$ di buka satu Sekolah Tinggi yang bernama Mahad Ilmy di kota Riyadh dan asy Syinqithipun dipercaya untuk mengajarkan bidang Tafsir dan Ushul Fiqh, dan ia mengajar sampai tahun 1381 H. (al Rumi, 1986: 124). Karirnya kemudian menanjak dengan berdirinya Universitas Islam Madinah dan dipercaya sebagai seorang tenaga pengajar. Di tengah kesibukannya, asy Syinqithi juga dipercaya sebagai Dosen Tamu di Sekolah Tinggi Hakim Riyadh dengan mengajar mata kuliah Tafsir dan juga Ushul Fiqh.

Profesi dosen dan juga ilmuan membuat karirnya birokratnya semakin baik dan melesat dengan cepat, ia menduduki jabatan Anggota Organisasi Majlis Ulama dan juga Anggota Dewan Pendiri Robithoh Alam Islami yang menjadi Donatur untuk membiayai Lembaga-lembaga Pendidikan di dunia Islam (al Rumi, 2003: 159). Akan tetapi asy Syinqithi sosok yang low profile, tidak banyak orang yang mengenalnya, karena tidak suka mempublikasikan diri, ketokohan dan juga keilmuannya. Sosoknya hanya dikenal kalangan dekat saja yang selalu menghadiri halaqah dan juga majlis ilmunya.

Setelah menjalankan aktivitas yang padat dengan belajar dan mengajar juga menulis, Syaikh Muhammad Amin asy Syinqithi dipanggil kembali oleh sang Khaliq hari kamis waktu dhuha tanggal 17-12-1993 M di kota Makkah dan di makamkan di komplek pemakaman umum maklah (Athiyyah, 1974: 22). Sebelum dimakamkan, terlebih dahulu al Marhum disholatkan di Masjidil Haram yang diimami oleh Mufti Kerajaan Arab Saudi Abdullah bin Abdul Aziz bin Baz dengan jamaah ribuan kaum muslimin. Penghormatan yang diberikan kepada al Marhum oleh orang yang ditinggalkannya belum selesai sampai disitu. Shalat Ghaib dilaksanakan selesai Shalat Isya keesokan harinya di Masjid Nabawi yang diimami oleh Imam Besar Mesjid Nabawi Abd Aziz bin Shalih al Shalih. 
Diantara karya-karyanya adalah: a. Tahqiq Kitab Salasil adz Dzahab. b. Al Asma wa as Sifat Aqlan wa Naqln. c. Dafu Iyham al Idhthirab an Ayat al Kitab. d. Adhwa al Bayan fi Tafsir al Quran bi al Quran. e. Manu Jawaz al Majaz fi al Munazzal li at Taabbud wa al Jaz. f. Mudzakkirah Ushul ala Roudhah an Nazhir. g. Adab al Bahtsi wa al-Munadzhoroh.

Tidak bisa dipungkiri bahwa kitab tafsir karya Syaikh asy Syinqithi yang berjudul Adhwa al-Bayan fi Iydhoh al Quran bi al Quran merupakan kitab Tafsir bi al Matsur dan diakui serta diapresiasi oleh banyak kalangan sebagai tafsir sunni (al Rumi, 1986: 122). asy Syinqithi dalam menulis kitab ini belum menyelesaikan sampai akhir surat an Nas sebagai Surat terakhir dalam al Quran. Ayat terakhir yang ditafsirkan_dalam kitabnya tersebut adalah surat

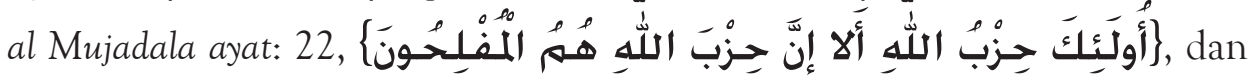
kemudian beliau dipanggil oleh Allah SWT.

2. Metodologi Penulisan Adhwa al Bayan fi Tafsir al Quran bi al Quran:

Kitab ini terdiri dari sembilan jilid besar dengan masa penulisan tiga belas tahun. jilid I - VII terbit tahun 1383 H, jilid ke-VIII pada tahun 1397 $\mathrm{H}$, sementara Jilid ke-IX tanpa tahun cetak. Tujuan penulisan kitab tafsir ini seperti yang sudah disebutkan asy Syinqithi dalam muqaddimahnya, Pertama: Menafsirkan al Quran dengan menggunakan al Quran, dikarenakan metode seperti ini merupakan kesepakatan kolektif ulama sebagai tafsir dengan derajat tertinggi. Kedua: Menjelaskan Hukum-hukum Fiqh (Hukum Islam) dengan menafsirkan ayat-ayat al Quran yang berkaitan dengan hukum-hukum fiqh dan juga sumber hukumnya dan dikomparasi dengan Sunnah dan juga opini ulama, memilih pendapat yang paling kuat, tanpa fanatik dengan madzhab tertentu atau ulama tertentu. (al Rumi, 1986: 127). Setelah mengkaji dan meneliti maka dapat disimpulkan bahwa Metodologi yang dominan dalam kitab ini adalah :

Pertama Menafsirkan al Quran dengan Metode al Matsur. Menafsirkan al Quran dengan al Quran merupakan metodologi dominan yang digunakan asy Syinqithi dalam tafsirnya, seperti dalam menafsirkan surat al Baqarah: 2 . Huda yang dimaksud dalam ayat tersebut menurut asy Syinqithi adalah Huda Khusus, yang merupakan hidayah dengan taufiq menuju agama yang haq, bukan Huda umum yang merupakan penjelasan terhadap yang haq. Selain itu, Al Quran bukanlah petunjuk bagi orang-orang yang tidak taqwa adalah mafhum mukhalafah ayat diatas (asy Syinqithi, 1995: 10). Asy Syinqithi juga menafsirkan ayat tersebut dengan surat Fushshilat ayat 44, al Isra ayat 82, dan Surat at Taubah ayat 124 . 
Contoh yang kedua, menafsirkan surat Ibrahim ayat 4. asy Syinqithi menafsirkan ayat tersebut dengan pendapatnya dalam memahami konten ayat, bahwa Nabi dan Rasul yang diutus oleh Allah SWT selalu menggunakan bahasa komunikasi ummatnya masing-masing, dikarenakan Nabi dan Rasul hanya diutus kepada umat tersebut. Lain halnya dengan Nabi Muhammad SAW yang diutus kepada seluruh ummat manusia tanpa kecuali (asy Syinqithi, 1995: 241). Hal ini menurut asy Syinqithi telah disebutkan al Quran dalam beberapa ayat, seperti al Araf ayat 157, al Furqan ayat 1 dan surat Saba ayat 28.

Kedua contoh diatas merupakan contoh metodologi asy Syinqithi dalam menafsirkan ayat-ayat al Quran dengan menggunakan ayat-ayat al Quran yang senada, dan hal ini merupakan metodologi yang sangat dominan dalam kitab tafsir ini.

Kedua Menafsirkan al Quran dengan Hadits Nabi SAW. Menafsirkan al Quran dengan Hadits Nabi SAW merupakan metodologi kedua yang diterapkan asy Syinqithi. Contoh yang pertama, dalam surat al Baqarah ayat 2, Riba yang dimaksud dalam ayat tersebut adalah Riba Nasyi'ah, hukumnya haram seperti kesepakatan ulama (asy Syinqithi, 1995: 171). Asy Syinqithi berargumen dengan Hadits Nabi SAW:

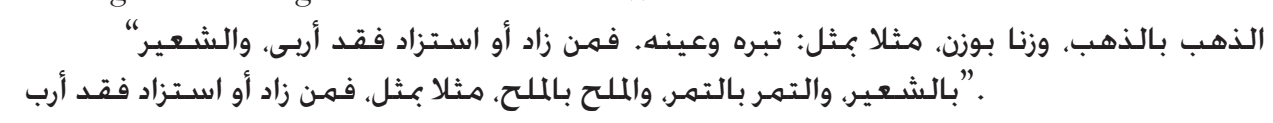

Contoh yang kedua tentang status musafir dan muqim dalam surat al Baqarah ayat 101. Asy Syinqithi berpendapat bahwa ayat diatas menjelaskan bolehnya seseorang melaksanakan shalat qashar ketika musafir. Limit waktu kategori seseorang muqim atau musafir adalah tiga hari, lebih dari tiga hari maka di kategorikan muqim dan wajib melaksanakan shalat secara sempurna (asy Syinqithi, 1995: 275). Asy Syinqithi berargumen dengan hadits yang berbunyi: "ثلاث للمهاجـر بعد الصدر".

Asy Syinqithi tidak membatasi metodologi menafsirkan al Quran dengan hadits yang shahih, akan tetapi juga menggunakan hadits-hadits yang dikategorikan Hasan dan Dho'if dalam memaparkan perbedaan penafsiran ayat-ayat hukum. Contoh argumentasi dengan Hadits Shahih dalam menafsirkan surat al Baqarah ayat 197. Kolektif Ulama berpendapat, Qurban yang dimaksud dalam ayat diatas adalah seekor domba. Akan tetapi ada sebagian kecil yang berpendapat bahwa qurban terbatas pada unta dan sapi saja. Kedua pendapat diatas berargumen dengan dua hadits Nabi SAW (asy Syinqithi, 1995: 83). 
Contoh argumentasi dengan Hadits Hasan dalam menafsirkan an Nisa ayat 43. Ayat tersebut merupakan argumentasi bolehnya tayammum dalam syariat Islam. Selanjutnya asy Syinqithi menjelaskan tehnis pelaksanaan tayammum dengan mengutip hadits yang diriwayatkan Shafwan bin Assal:

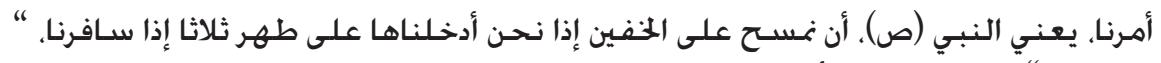

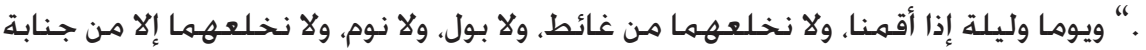

Hadits ini diriwayatkan oleh Imam Ahmad, Ibnu Khuzaimah, Turmudzi, Nasai, Ibnu Majah, Ibnu Hibban dan Baihaqi. As Syaukani menyatakan dalam Nail al Autornya bahwa Hadits diatas merupakan Hadits Hasan karena sanadnya ada Usman bin Abi an Nujud seorang rawi yang jujur tapi hafalannya buruk (asy Syinqithi, 1995: 347).

Contoh argumentasi dengan Hadits Dho' îf, seperti dalam menafsirkan surat an Nahl ayat 115, asy Syinqithi memaparkan, berdasarkan ayat ini, Hanafiah berpendapat hewan yang hidup di dua alam (amphibi) merupakan hewan yang haram sama sekali, sedangkan hewan yang hidup di air saja atau laut saja merupakan hewan yang halal. Jika hewan air tawar maupun asin mati dalam air dan mengambang maka dimakruhkan mengkonsumsinya Berdasarkan hadits yang diklassifikasikan sebagai Hadits Dhoof karena sanadnya dari Ibnu Abi Dhib dari Ibnu az Zubair dari Jabir dari Rasul SAW (asy Syinqithi, 1995: 52).

Ketiga: Menafsirkan al Quran dengan Pendapat Shahabat. Shahabat adalah orang yang bertemu dengan Nabi SAW dan masuk Islam. Shahabat adalah generasi pertama yang mendengarkan wahyu dari Nabi SAW secara langsung. Shahabat pulalah yang disebut dengan Murid Nabi SAW. Diantara sekian banyak Shahabat, ada yang meriwayatkan tafsir al quran didengar dari Nabi langsung atau yang didengar dari sesama shahabat. Tafsir Shahabat banyak sekali ditemukan dan dipakai asy Sinqithi sebagai sumber primer, antara lain surat al Baqarah ayat 276. Ayat tersebut merupakan argumentasi spesifik haramnya riba Fadhal. Ibnu Abbas pada awalnya melakukan transaksi riba Fadhal. Umar bin Khatthab dan anaknya Abdullah kemudian menegaskan tentang haramnya riba Fadhal kepada Ibnu Abbas yang kemudian menerima dan beristighfar dan berkata tentang keduanya, "mereka hafal yang belum saya hafalkan" (asy Syinqithi, 1995: 173).

Contoh yang kedua dalam menafsirkan surat al Haj ayat 27. Asy Syinqithi mengatakan ayat tersebut merupakan penjelasan seruan menunaikan ibadah haji. Ia menambahkan relevansi ayat ini dengan sebuah hadits yang 
membolehkan "haji badal" sesuai dengan ketentuan dan persyaratan yaitu Hadits yang diriwayatkan Ibnu Abbas (asy Syinqithi, 1995: 320).

إن فريضة الله على عباده في الحهج أدركت أبي شيخا كبيرا لا يستطيع أن يثبت على....

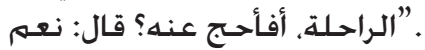

Keempat Menafsirkan al Quran dengan Pendapat Tabiin. Tabiin adalah orang yang bertemu dengan Shahabat dan memeluk Islam. Tabiin merupakan generasi kedua setelah generasi shahabat. Tabiin yang belajar dan berguru kepada shahabat tidaklah sedikit. Namun diantara tabiin itu ada yang terkenal dikarenakan gurunya merupakan shahabat Nabi yang terkenal atau pendapat dan argumentasinya diabadikan dan dikutip oleh ilmuan dan cendekiawan Islam dalam karya-karya mereka. Diantara pendapat Tabiin yang dikutip oleh asy Syinqithi sebagai argumentasi seperti dalam menafsirkan al Quran dalam surat al Baqarah ayat 173. Ayat ini menjelaskan haram mengkonsumsi binatang yang disebutkan didalam ayat. Asy Syinqithi mengutip pendapat al Qurtubi yang berargumentasi dengan pendapat Mujahid tentang pengertian alIdhthirar (al Dhar) yaitu: "terpaksa mengkonsumsi yang diharamkan". Terpaksa mengkonsumsi hewan yang haram seperti seorang muslim yang tertawan musuh dan dipaksa untuk mengkonsumsi binatang babi atau berbuat maksiat yang lain (asy Syinqithi, 1995: 62).

Kelima Mendalami asal kata bahasa Arab serta ilmu pendukung yang diperlukan seperti Sharaf dan juga argumentasi dengan Syair Arab. Bahasa Arab merupakan bahasa yang sangat fenomenal ditinjau dari berbagai sudut pandang. Di katakan fenomenal dikarenakan "banyak kata beragam arti". Dalam kaitannya dengan al Quran yang berbahasa Arab ditemukan adanya rahasia-rahasia yang tersembunyi dibalik kata maupun kalimat. Dalam al Quran banyak ditemukan Allah SWT berkata kepada Nabi Nya Muhammad SAW. Dalam hal ini, asy Syinqithi selalu melakukan investigasi mendalam kata demi kata dalam ayat, dan menggunakan pendekatan nahwu, Sharf dan Syaiir Arab.

Keenam: Investigasi Masalah-masalah yang berkaitan dengan Ushul al Figh. Asy Syinqithi dalam tafsirnya selalu menjelaskan hukum-hukum yang terkandung didalam ayat dengan panjang lebar. Contohnya dalam menafsirkan surat al Baqarah ayat 229. Menurut asy Syinqithi ayat ini menjelaskan Thalaq yang memiliki hak rujuk hanya dua kali, apabila thalaq sudah jatuh tiga maka dengan sendirinya gugur hak rujuk dan hanya ada akad nikah baru. Imam Bukhari menurut asy Syinqithi berpendapat thalaq dengan satu kali ucapkan akan jatuh tiga. Akan tetapi pendapat ini ditentang oleh Ibnu Hajar yang mengatakan thalaq tiga satu kali ucap tetap jatuh satu thalaq (asy Syinqithi, 1995: 104). 
Adhwa al Bayan fi Iydhoh al Quran bi al Quran karya besar Imam asy Shinqithi merupakan tafsir kontemporer yang pendapat-pendapat didalamnya sangat berpegang teguh kepada metode Matsur. Asy Syinqithi dalam penyusunan tafsirnya juga sangat terpengaruh dengan mazhab Ahlu as Sunnah wa al Jamaah, bahkan asy Syinqithi merupakat penganut madzhab tersebut. Asy Syinqithi juga menggunakan metodologi yang sangat kuat dalam hal istinbath hukum. Hal itu bisa disaksikan ketika asy Syinqithi menafsirkan ayat-ayat yang berkaitan dengan hukum.

B. Jami al Bayan fi Tawil al Quran

1. Riwayat Hidup Penyusun

Nama lengkap Penyusun adalah Muhammad bin Jarir bin Yazid bin Kholid at Thabari dengan kuniah Abu Jafar. Lahir di Thibristan tahun $224 \mathrm{H}$ (Ibnu Khalkan, tt: 192). Menetap di Baghdad dan disana jugalah beliau wafat dan dimakamkan. Ciri-ciri fisiknya yang utama berkulit coklat, berperawakan langsing, mata besar dan bicaranya yang tegas dan fasih (az Zirikli, 2002: 69), rambut hitam jengat dengan jenggot lebat (al Hamawi, 1993: 2441). Selain ciri-ciri diatas, Imam Thabari juga memiliki kepribadian yang luhur berupa sifat-sifat yang sangat baik, seperti yang digambarkan oleh Muhaisin: "Imam Thabari adalah seorang yang wara, sangat taqwa, tawadu, selalu menjaga harga diri, berani, zuhud, berpenampilan elegan, menikmati apa yang telah diberikan Allah dan sopan dalam segala kondisi” (Muhaisin, 1992: 145). Sifatsifat yang digambarkan diatas tidak dimiliki oleh setiap ulama, dan hal ini dapat mempertegas betapa Imam Thabari terpelihara dari sifat-sifat negatif yang bisa meruntuhkan kehormatan, kredibilitas, integritas dan kapabilitasnya yang tetap terjaga sampai akhir hayatnya.

Imam Thabari kecil menghabiskan masa kanak-kanaknya di Thibristan. Ayahnya sudah menyerahkan Thabari kecil ke Ulama-ulama Thibristan saat usianya belum cukup memasuki jenjang pendidikan. Dengan kecerdasan yang luar biasa, ternyata membuat Thabari kecil bisa menerima ilmu dan keilmuan dari guru-gurunya, sehingga saat usianya belum genap tujuh tahun beliau sudah hafal al Quran, menjadi Imam shalat berjamaah saat usianya menginjak delapan tahun, dan ia sudah menulis Hadits dengan sanad dan matannya saat berusia Sembilan tahun (Muhaisin, 1992: 144). Hal ini menunjukkan anugerah yang luar biasa berupa tingkat kecerdasan yang tinggi terhadap diri seorang Imam Thabari, dikarenakan hal yang sangat jarang terjadi apabila anak kecil usia tujuh tahun sudah hafal al Quran dan usia delapan tahun sudah mengimami shalat berjamaah yang makmumnya didominasi oleh orang dewasa, 
dan sembilan tahun sudah menuliskan dan membukukan hadits lengkap dengan sanad dan juga matannya. Setelah beranjak dewasa, Imam Thabari melanjutkan pengembaraan ilmiahnya untuk belajar ke berbagai wilayah yang masih termasuk dalam wilayah teritorial Islam, seperti Iraq, Syam, Hijaj dan Mesir. Di Wilayah-wilayah ini Imam Thabari kemudian menuntut ilmu dalam berbagai disiplin ilmu kepada ulama-ulama yang kompeten dibidangnya. Akan tetapi, Perjalanan ilmiah ke Mesirlah yang paling berdampak terhadap keilmuan seorang Imam Thabari.

Imam Thabari dikenal sebagai ulama yang menguasai berbagai disiplin ilmu utamanya jenis keilmuan yang tumbuh dan berkembang saat itu. Selain memiliki karya yang sangat terkenal dan fundamental dibidang tafsir, Imam Thabari juga memiliki karya-karya dibidang ilmu yang lain, seperti Tarikh, Aqidah dan juga Qiraat. Untuk lebih fokus, peneliti mencantumkan sebagian karya-karya tersebut, seperti: Jami al Bayan fi Tawil al Quran dalam bidang tafsir, Akhbar ar Rusul wa al Mulk dalam bidang tarikh ( sejarah ), Al Mustarsyid dan Juz fi al Itiqad dalam bidang Aqidah dan Al Qiraat dalam bidang qiraat.

Karya-karya dengan disiplin ilmu yang berbeda dengan sendirinya telah menunjukkan sisi keilmuan dari seorang Imam Thabari dan juga kelebihannya. Dalam perkembangannya, Imam Thabari kemudian diakui oleh mayoritas ulama saat itu sebagai seorang yang memiliki tingkat keilmuan Mujtahid dalam bidang fiqh, sehingga dikabarkan Imam Thabari memiliki madzhab sendiri dan tidak bertaqlid kepada ulama-ulama mazhab fiqh sebelumnya, akan tetapi banyak ulama yang kemudian bertaqlid kepadanya.

2. Metodologi Penulisan Jami al Bayan fi Tawil al Quran:

Jami al Bayan fi Tawil al Quran merupakan karya fenomenal di bidang tafsir yang memiliki metodologi penyusunan dan penulisan yang tidak akan pernah "terulang" sepanjang sejarah. Imam Thabari dalam tafsirnya merumuskan dan mengajukan metodologi yang popular pada masanya sehingga hasil dari metodologi saat itu masih menjadi perbincangan hangat dikalangan akademisi sampai saat ini.

Imam Suyuthi menyebutkan bahwa kitab Jami al Bayan fi Tawil al Quran merupakan kitab tafsir terbesar sepanjang sejarah (al Hasan, 2000: 261). Sedangkan Khatib al Baghdadi menyebutkan metodologi kitab tafsirnya Imam Thabari merupakan karya yang belum dan tidak akan pernah ditulis oleh orang lain lagi (Muhaisin, 1992: 151). Imam Ibnu Taimiah mengatakan Tafsir Imam Thabari merupakan kitab tafsir yang paling valid dari seluruh kitab tafsir yang beredar, sanadnya shahih dan tidak mengandung bidah 
(Thabari, 2004: 542). Ketiga ilmuan dan pakar diatas menyebutkan apresiasi dan penghargaannya kepada Imam Thabari dan karyanya yang tidak akan ada yang mampu menyusun dan menulis tafsir lagi seperti yang dilakukan oleh Imam Thabari.

Metodologi yang dirumuskan oleh Imam Thabari dalam Jami al Bayan fi Tawil al Quran, merupakan metodologi khusus dan hanya dipakai dalam menyusun kitab tafsirnya, dan dapat dirinci dalam poin-poin berikut ini:

Pertama Metodologi Matsur. Seperti halnya asy Syinqithi, Imam Thabari yang jauh lebih senior sudah terlebih dahulu menerapkan metode Matsur dalam menafsirkan al Quran. Penulis merasa tidak perlu lagi memuat metode Matsur dan contohnya, dikarenakan metode Matsur yang diterapkan Imam Thabari sama persis seperti yang diterapkan asy Syinqithi. Hanya saja ada perbedaan yang mendasar dalam metodologi Matsur yang diterapkan keduanya. Menafsirkan al Quran dengan al Quran lebih mendominasi dalam tafsirnya Asy Syinqithi, sementara tafsir al Quran dengan Hadits Nabi SAW lebih mendominasi dalam tafsirnya Imam Thabari.

Kedua Validasi Sanad. Imam Thabari merupakan seorang yang terpercaya dalam memvalidasi sanad dan pencantuman rawi. Hal itu dikarenakan Imam Thabari sering berinteraksi dan berguru kepada Ulama-ulama besar saat itu dan dari merekalah Imam Thabari mendengar dan mengambil riwayat hadits. Apabila kondisionalnya Imam Thabari bersama dengan ulama yang lain dalam meriwayatkan, beliau menyampaikan dengan pola bahasa "haddatsana", sedangkan kondisional hanya Imam Thabari seorang yang meriwayatkan maka Imam Thabari menyampaikannya dengan pola bahasa "haddatsani". Contoh sanad yang menggunakan kalimat "haddatsana", dalam menafsirkan Surat alMujadalah ayat 4. Imam Thabari meriwayatkan bahwa yang dimaksud dengan "hudud Allah" dalam ayat tersebut adalah "syuruth Allah" yang berarti "syaratsyarat Allah", Berdasarkan Atsar yang menggunakan kalimat "haddatsana" yang diriwayatkan oleh as-Saddy (Thabari, 2000: 68).

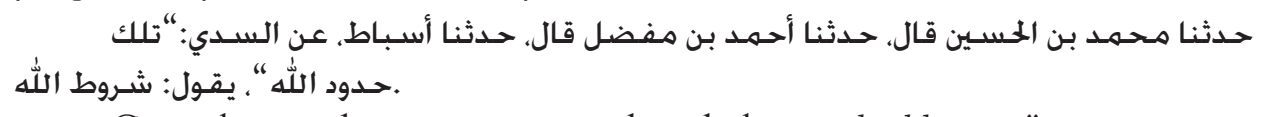

Contoh sanad yang menggunakan kalimat «haddatsani" seperti yang diriwayatkan Imam Thabari bahwa makna dari "hudud Allah" dalam ayat tersebut juga "thoatu Allah" yang artinya mentaati Allah, berdasarkan atsar yang menggunakan kalimat "haddatsani":

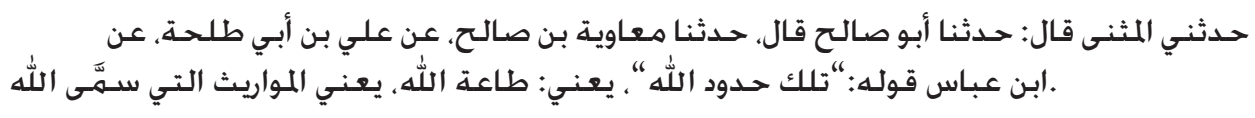

Ulul Albab Volume 14, No.2 Tahun 2013 
Kedua Argumentasi dengan Qiraat. Imam Thabari selalu memaparkan dengan panjang lebar Qiraat-qiraat yang muncul dikalangan ulama dan selalu memvalidasi setiap Qiraat tersebut, seperti dalam menafsirkan surat al Baqarah ayat 119 (Thabari, 2000: 558). Imam Thabari meriwayatkan adanya berbedaan qiraat dalam kata "wala tusalu". Qiraat yang umum menurutnya dibaca dengan "ta dan lam dhammah". Jika demikian maka makna ayat diatas: "ya Muhammad, sesungguhnya kami mengutusmu dengan haq menyampaikan kabar gembira juga peringatan, tugasmu hanya menyampaikan dan memberi peringatan, dan engkau tidak perlu bertanggung jawab terhadap orang yang masih ingkar, dan itulah penghuni neraka jahim". Penduduk Madinah membaca dengan qiraat "wa la Tasal" (ta nashab dan lam jazam) ( larangan ). Jika demikian maka artinya: "sesunguhnya kami mengutusmu dengan haq membawa berita gembira dan juga duka cita untuk menyampaikan apa yang akan disampaikan, bukan untuk bertanya tentang penghuni neraka jahîm, maka jangan tanyakan kondisi mereka". Imam Thabari mengatakan pendapat yang pertama yaitu "ta dan lam dhammah" yang paling kuat, karena Allah SWT menceritakan kisah kaum yahudi dan nashrani, kesesatan, kekufuran mereka kepada Allah SWT dan kedurhakaan mereka terhadap Nabi-nabiNya, lalu Allah melanjutkan dengan statmentNya dalam ayat tersebut.

Ketiga Argumentasi dengan Sya'ir Arab. Ini dilakukan oleh Imam Thabari ketika menemukan arti yang berbeda dalam satu kata. Contohnya dalam menafsirkan surat an Nisa ayat 4, ia mengatakan asal kata dari ayat "hanian" dalam ayat tersebut adalah "hanaat albaru bi al qathirani" yaitu menempati isim

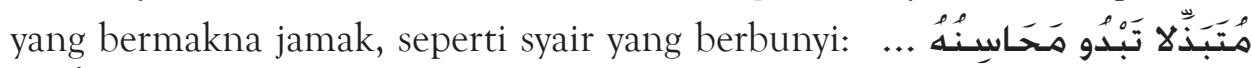
Seolah-olah ayat diatas berma'na: "maka konsumsilah óbat yang menyémbuhkan" (Thabari, 2000: 559).

Keempat Argumentasi Nahwu dengan Madzhab Bashra dan Kufah. Berargumentasi dengan ilmu Nahwu dan Sharf sangat sering dilakukan Imam Thabari bila menemukan ayat yang berkaitan dengan makna-makna etimologi. Contoh Argumentasi Nahwu dalam menafsirkan surat al Imran ayat 7, yang menurut madzhab Basra, Sebagian ayat diatas berbunyi "hunna umm al-kitab" bukan dengan kalimat "hunna ummaat al kitab". Hal itu senada dengan seseorang yang berkata "ma li anshar", maka boleh dijawab dengan "ana anshaaruka", atau dalam kosakata yang lain seperti "maa lii nadziir" maka boleh dijawab dengan "nahnu nadziiruka" (Thabari, 2000: 171). Contoh Argumentasi Nahwu Menggunakan madzhab Kufah seperti dalam menafsirkan surat an Nisa ayat 4. Kata "an-Nafsu" dalam ayat tersebut boleh menggunakan jamak 
atau tunggal. Apabila demikian maka ayat diatas akan mengalami perubahan kalimat dan menjadi " $f a$ in thibna lakum an syai minhu nafsan atau anfusan" (Thabari, 2000: 559).

Kelima Tarjih Ragam Pendapat yang Muncul. Ragam pendapat ulama yang muncul selalu diakomodasi oleh Imam Thabari dengan memaparkannya dengan rinci, dan selalu ditarjih pendapat mana yang paling valid. Contohnya dalam menafsirkan (Thabari, 2000: 554) surat an Nisa ayat 4. Imam Thabari memaknai ayat tersebut dengan "berikanlah wanita mahar mereka sebagai pemberian yang wajib". Yang mengatakan makna seperti ini adalah Qatadah dan Ibnu Juraij. Sementara itu, ada juga ulama memaknai dengan "memberikan mahar kepada wali wanita", karena wali boleh mengambil mahar. Yang mengatakan seperti ini adalah Abu Shalih. Ada pula yang memaknai ayat diatas dengan "memberikan saudara perempuannya kepada laki-laki lain, dan si laki-laki mendapatkan saudara perempuan laki-laki yang lain itu" (tukaran saudara perempuan). Dan yang mengatakan seperti ini adalah Mutamir bin Sulaiman. Imam Thabari mentarjih pendapat-pendapat diatas dan mengatakan bahwa pendapat yang paling valid menurutnya adalah pendapat yang pertama.

Inilah pemaparan sebagaian contoh dalam metodologi yang digunakan Imam Thabari dalam menafsirkan al Quran. Imam Thabari selalu menyebutkan perbedaan pendapat dikalangan ulama dalam menafsirkan ayat, Perbedaan pendapat yang berkaitan dengan ragam pendapat dalam tafsir, validitas matan dan sanad, Qira'at maupun Hukum-hukum yang terkandung dalam ayat, merupakan metodologi-metodologi yang banyak ditemukan dalam tafsirnya.

\section{Tafsir al Quran al Azhim}

1. Riwayat Hidup Penyusun

Imaduddin Ismail bin Umar bin Katsir bin Dhou, al Quraisy, al Bashrawi, ad Damsyiqi dan asy Syafii merupakan nama lengkap Ibnu Katsir dengan kuniah Abu al Fida (al-Mazzi, 1417 H: 64). Dilahirkan di Desa Majdal wilayah Bashra pada tahun $701 \mathrm{H}$ (al Husaini, 1419 H: 38). Ibunya berasal dari desa Majdal, ayahnya al-Khathib Syihab ad-Din Umar bin Katsir merupakan ulama yang faqih dan juga Dai dan berasal dari kota Bashra (Ibnu Katsir, 1416 H: 6).

Ayahnya wafat ketika usianya menginjak empat tahun sehingga Ibnu Katsir kecil berada dibawah pengawasan saudaranya syaikh Abd. al Wahhab dan kemudian membawanya untuk pindah domisili ke kota Damasqus. Saudaranya inilah tempat Ibnu Katsir belajar Fiqh pertama kalinya (azh Zhahiri, tt: 414). 
Ketika usianya sudah menginjak sepuluh tahun, Ibnu Katsir menghatamkan hafalan al Quran, tepatnya pada tahun 711 H (Ibnu Katsir, 1416 H: 6). Di kota Damasqus, Ibnu Katsir kecil memulai petualangan ilmiahnya dengan menuntut ilmu di beberapa halaqah syaikh yang dipandang kompeten saat itu, belajar Fiqh kepada syaikh Burhan ad Din al Fazzari, juga kepada Ibnu asSuwaidi, al Qasim bin Asakir. Ibnu Katsir kemudian menikahi putri syeikh al Mazzi sekaligus belajar berbagai disiplin ilmu kepada Syeikh al Mazzi yang membuat Ibnu Katsir di kemudian hari memiliki kemampuan akademik diberbagai bidang keilmuan seperti Fiqh, Tafsir dan juga Nahwu (al Husaini, $1419 \mathrm{H}: 38$ ). Selain menuntut ilmu kepada ulama-ulama yang terkenal diatas, Ibnu Katsir tidak berpuas diri, akan tetapi masih belajar ilmu yang lain kepada Isya bin Abd ar Rahman al Muthim, Ibnu asy Syiradzi, Ishaq al Amidi dan Muhammad bin az Zarad. Ibnu Katsir juga melakukan perjalanan ilmiahnya ke Mesir dan menuntut ilmu kepada Abu al Fattah ad Dabbusy, Ali bin al Alwani dan Yusuf al Hatni (Taqiyuddin, 1990: 472). Ibnu Katsir juga belajar kepada syeikh Ibnu Taimiah yang bernama al Barzali, Ibnu az Zamalkani dan juga Ibnu Qadhi Shabah. Tidak dijelaskan disiplin ilmu yang dipelajari Ibnu katsir kepada ulama-ulama yang diatas.

Selain kompetensi keilmuan Ibnu Katsir yang dikenal dibidang tafsir dan juga tarikh (sejarah), Ibnu Katsir juga layak di sejajarkan dengan seorang imam yang memiliki kompetensi dibidang Hadits, terutama dibidang al Jarh wa at Tadil, seperti terlihat dari karya-karyanya dalam bidang Hadits, seperti Takhrij al Ahadits Mukhtashar Ibnu Hajib, ia juga menyusun kembali sub topik Musnad Ibnu Hanbal berdasarkan huruf Hijai, dan juga menyusun kitab Musnad asy Syaikhan (as Suyuthi, tt: 238).

Perjalanan ilmiah Ibnu Katsir juga diwarnai dengan fanatisme terhadap pemikiran dan hasil Ijtihad, dalam hal ini Ibnu Katsir merupakan murid Ibnu Taimiyah yang paling fanatik. Ibnu Katsir begitu mendalami ilmu dan keilmuan Ibnu Taimiyah dalam bidang fiqh dan juga tafsir, sehingga Ibnu Katsir mengikut banyak pendapat-pendapat yang asal muasalnya Ibnu Taimiyah, seperti pendapat Ibnu Taimiyah yang mengatakan: "Thalaq tiga dengan sekali ucap maka jatuh tiga" (Abu Shahbah, tt: 128).

Karya ilmiah Ibnu Katsir sangatlah banyak dan beragam serta tidak terbatas dalam satu disiplin kopetensi keilmuan. Diantara karya-karya tersebut seperti Tafsir al Quran al Adzhim, Al Bidayah wa an Nihayah, Taqwim al Buldan, As Sirah an Nabawiyah, Thabaqat al Fuqaha asy-Syafi'iyyin, At Takmil fi al Jarhi wa at Tadil wa Marifat ats Tsiqat wa adh Dhuafa wa al Majahil, Al Had wa as 
Sunan fi Ahadisi al Masanidi wa as Sunan, Takhrij al Ahadits Mukhtashar Ibnu Hajib dan Al Ahkam ala Abwab at Tanbih (al Baihaqi, 1425: 536).

Setelah melalui kehidupan ilmiah yang sangat berkualitas, dengan menghasilkan murid-murid sebagai generasi penerus dan karya-karya fenomenal diberbagai disiplin ilmu, Ibnu Katsir kemudian dipanggil kembali oleh yang maha kuasa dalam usia tujuh puluh satu tahun, tepatnya pada tahun $772 \mathrm{H}$ (al-Bigha, 1998: 254).

2. Metodologi Penulisan Tafsir al Quran al Adzhim:

Tafsir al Quran al Adzhim merupakan karya fenomenal Ibnu Katsir di bidang tafsir. Kitab ini merupakan referensi ke tiga dalam silsilah kitab tafsir yang mutamad dikalangan Sunni. Bisa dikatakan bahwa kitab tafsir ini merupakan ringkasan dari kitab tafsir karya Imam Thabari yang berjudul Jami al Bayan fi Tafsir al Quran (al Utsaimin, 1995: 62), sehingga dapat dikategorikan bahwa tafsir ini menempati rangking kedua dari sisi ke validan setelah kitab Jami al Bayannya Imam Thabari (al Rumi: 2003: 157). Kitab Tafsir ini memiliki karakteristik Metodologi yang berbeda dengan kitab tafsir yang lain seperti karyanya Imam asy Syinqithi dan Imam Thabari (al Bigha, 1998: 156). Diantara Metodologi tersebut:

Pertama Metodologi Matsur. Seperti halnya asy Syinqithi dan Thabari, Ibnu Katsir pun menafsirkan al Quran dengan metodologi matsur. Ada perbedaan yang mendasar antara Thabari dan Ibnu Katsir, Thabari menafsirkan ayatayat al Quran kalimat demi kalimat dalam ayat-ayat yang terpisah, sementara Ibnu Katsir menafsirkan ayat demi ayat secara sempurna. Ibnu Katsir dalam metodologi tafsirnya dengan matsur dan penulis tidak mencantumkan contohcontoh yang dimuat Ibnu Katsir dalam kitabnya, karena penulis merasa cukup mencantumkan contoh metodologi matsur dalam pembahasan tafsir asy Syinqithi dan Thabari diatas dan tidak ada perbedaan di antara ketiganya. Namun, ada metodologi tambahan yang dimuat Ibnu Katsir dalam kitab tafsirnya dan belum ada di muat oleh asy Syinqithi dan Thabari, seperti:

Pertama Ibnu Katsir Menjelaskan Keutamaan setiap Surat. Setiap surat maupun ayat dalam al Quran memiliki kelebihan, keutamaan ataupun faedah yag berbeda-beda. Hal ini terungkap berdasarkan hadits Nabi SAW. Ibnu Katsir kemudian mengutip dan memaparkan hadits-hadits tersebut dalam menafsirkan al Quran, contohnya dalam menafsirkan surat al Fatihah dan al Baqarah dengan memaparkan kelebihan kedua surat tersebut berdasarkan hadits Nabi SAW. Al Fatihah disebut Nabi dengan "memiliki kandungan besar dan luas" seperti yang diriwayatkan oleh Abu Said al Mualla (Ibnu Katsir, 
1419 H: 20). Nabi juga menyebutkan untuk membaca surat al Baqarah "ketika ada orang yang wafat" dalam hadits yang diriwayatkan oleh al Maghafal bin Yassar (Ibnu Katsir, 1419 H: 61).

Kedua Metodologi Qiraat. Ibnu Katsir juga memaparkan Qiraat-qiraat yang berbeda di kalangan ulama, dan memvalidasi qiraat yang paling kuat serta argumentasinya. Contohnya dalam menafsirkan surat al Fatihah ayat 4, Sebagian ulama membaca dengan "maliki" ( lam kasrah) sedangkan yang lain membaca dengan "malki" ( lam sukun ). Keduanya shahih ( valid ) dan mutawatir. Menurut Ibnu Katsir ada juga yang membaca dengan "maliku" ( lam kasrah dan ya ). Sedangkan nafi' membacanya dengan "maliki”. Qiraat yang pertama dan kedua divalidasi dan dua-duanya valid versi Ibnu Katsir (Ibnu Katsir, 1419 H: 46).

Ketiga Pengelompokan Ayat, Surat, dan Hadits Dalam Satu Topik. Ibnu Katsir mengelompokkan ayat-ayat yang senada dan saling berkaitan dalam surat yang sama dan di dukung dengan Hadis serta menjelaskan derajat hadits tersebut, shahih, dho'if atau munkar. Contohnya dalam menafsirkan surat al Araf ayat 28-30 (Ibnu Katsir: 1419 H: 361-362). Ayat-ayat tersebut memiliki topik yang saling berkaitan, dan Ibnu Katsir mengutip beberapa pendapat yang berbeda dalam menafsirkan potongan ayat "kama badaakum tauduna", yaitu: Mujahid menafsirkan dengan "kamu dihidupkan setelah matimu". Hasan al Bashri menjelaskan "sebagaimana kamu memulainya didunia akan begitu juga kembalimu di hari kiamat dalam kondisi hidup". Qatadah menafsirkan "memulai penciptaan mereka, sebelum mereka memiliki sesuatu mereka pergi dan kemudian kembali". Abd.. Rahman bin Zaid bin Aslam menafsirkan "sebagaimana kamu mula-mula diciptakan seperti itulah kamu diciptakan saat terakhir". Pendapat yang terakhir yaitu pendapat Abd. Rahman bin Zaid bin Aslam merupakan pilihan Ibnu Katsir, berdasarkan hadits Ibnu Abbas yang di riwayatkan Bukhari dan Muslim yang menurut Ibnu Katsir merupakan hadits shahih yaitu:

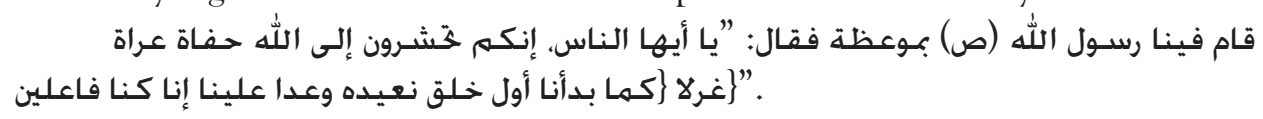

Selain mengutip pendapat tabiin, Ibnu Katsir juga mengutip pendapat Shahabat, seperti as Saddi "sebagaimana kamu diciptakan ada yang mendapat petunjuk dan ada pula yang sesat". Ibnu Abbas menafsirkan dengan "Bahwa Allah SWT menciptakan ada yang mukmin dan ada juga yang kafir, kemudian kembali ke hari kiamat persis seperti diciptakan ada yang mukmin dan juga kafir". Penafsiran Ibnu Abbas ini diperkuat dengan Hadits yang diriwayatkan Ibnu Masud: 


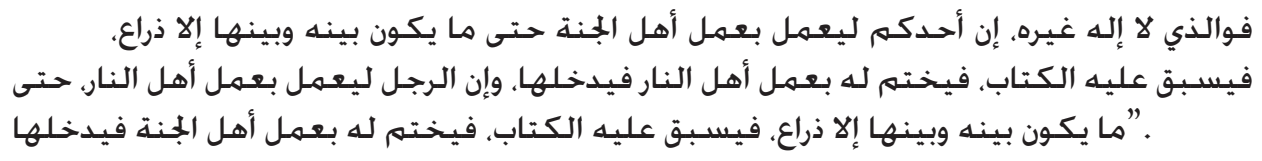

Keempat penjelasan Israiliat. Ibnu Katsir juga menjelaskan kisah-kisah dan cerita Israiliat dalam tafsirnya sebagai bentuk pengetahuan yang dipublikasikan dan bukan sebagai argumentasi pendukung. Contoh menafsirkan dengan penjelasan Israiliat seperti dalam menafsirkan surat al Baqarah ayat 251 (Ibnu Katsir, 1419 H: 252). Ayat tersebut menjelaskan Daud dan tentaranya menang perang melawan Jalut yang memiliki tentara yang lebih besar dan hebat. Daud sendiri yang membunuh Jalut. Akan tetapi, Daud menggunakan "ketapel" dalam membunuh Jalut merupakan Israiliat menurut Ibnu Katsir. Contoh yang kedua, dalam menafsirkan surat al Araf ayat 24 yang menjelaskan perintah Allah SWT untuk turun dari surga ke bumi. Yang dimaksud dalam ayat tersebut adalah Adam, Hawa, Iblis dan juga Ular. Nama tempat turun Adam, Hawa, Iblis dan juga Ular merupakan cerita Israiliat menurut Ibnu Katsir (Ibnu Katsir, 1419 H: 252).

Kelima Validasi pendapat dan permasalahan Fiqh. Ibnu Katsir juga selalu memaparkan perbedaan pendapat dan juga permasalahan fiqh yang terjadi dikalangan ulama. Hal yang dilakukan oleh Ibnu Katsir adalah memvalidasi pendapat yang paling valid dan kuat. Contohnya dalam menafsirkan surat an Nisa ayat 101. Ayat tersebut menjelaskan bolehnya Jama dan Qashar bagi orang yang sedang melakukan perjalanan atau traveling. Ibnu Katsir mengutip pernyataan mayoritas ulama yang membolehkan Qashar terhadap shalat empat raka'at menjadi dua raka' at dengan syarat traveling yang dilakukan merupakan traveling kategori taat kepada Allah SWT, seperti Jihad, Haji, Umrah, Studi atau Ziarah. Sedangkan Syafii tidak mensyaratkan traveling jarak dekat dan hukumnya mubah, seperti mubahnya hukum mengkonsumsi bangkai dalam kondisi darurat. Sedangkan Abi Hanifah, Sufyan ast Tsauri dan Daud azh Dzohiri berpendapat bahwa travelingnya mutlak tanpa ada perbedaan antara traveling yang mubah maupun yang haram seperti traveling untuk melakukan perampokan. Abi Hanifah berargumentasi dengan umumnya maksud ayat diatas (Ibnu Katsir, 1419 H: 348).

Keenam Mengutip Hadits pendukung yang diriwayatkan Ibnu Abi Hatim dan Thabrani. Hadits-hadits yang diriwayatan Bukhari, Muslim dan Kitab yang Enam selalu menjadi rujukan utama Ibnu Katsir dalam menafsirkan ayat-ayat al-Quran. Selain itu, Ibnu Katsir juga menyebutkan hadits pendukung yang 
senada dan mengkuatkan yang diriwayatkan oleh Ibnu Abi Hatim dan juga Thabrani.

Metodologi-metodologi diatas inilah yang biasa ditemukan didalam kitab tafsirnya Ibnu Katsir yang berjudul "Tafsir al Quran al Azhim”. Peneliti juga menjelaskan contoh-contoh metodologi yang didapat dalam kitab tersebut secara rinci dan juga valid.

D. Ad Dar al Mantsur fi at Tafsir bi al Matsur

1. Riwayat Hidup Penyusun

Nama lengkapnya Abd Rahman bin Abi Bakr bin Muhammad bin Abi Bakr bin al Hammam al Asyuthi, asSayafii. Lahir dibulan Rajab tahun 849 $\mathrm{H}$ di kota Asyuth yang terletak di propinsi paling barat Republik Arab Mesir (Muhaisin, 1992: 124).

Imam Suyuthi tumbuh dan berkembang dikota Kairo dalam kondisi yatim, Ayahnya meninggal saat usianya lima tahun. Perjalanan ilmiah yang dilakukannya pertama sekali adalah menghafal al Quran, dan sudah khatam hafalan al Quran saat usianya belum sampai delapan tahun. Pasca hafal al Quran, yang dilakukan kemudian oleh Imam Suyuthi dalam perjalanan ilmiahnya adalah menghafal kitab "al Umdah", mempelajari Metodologi Fiqh, Ushul Fiqh serta menghafal kitab "Alfiah” Ibnu Malik (Muhaisin, 1992: 125). Imam Suyuthi kemudian menuntut ilmu dengan menghadiri halaqah-halaqah dan majlis ulama yang kompeten pada masanya. Selain itu, Imam Suyuthi juga rajin melakukan perjalanan ilmiah ke kota-kota sekitar kelahirannya Asyuth, seperti al-Fayyoum, Dimyath, Mahallat Kubra serta kota-kota yang lain di negeri Mesir. Imam Suyuthi tidak berhenti belajar dan menuntut ilmu sampai disitu saja, akan tetapi Imam Suyuthi kemudian melakukan perjalanan panjangnya dalam menuntut ilmu keberbagai negeri yang masih masuk dalam wilayah Timur Tengah seperti negeri Syam, Hijaz, Yaman, India, Marokko dan negeri Takrour (Muhaisin, 1992: 124).

Hasil perjalanan ilmiahnya dalam menuntut ilmu ke berbagai guru dan syaikh yang mencapai seratus lima puluh (al Hasan, 2000: 131), ia menjadi seorang ilmuan yang paling dikenal pada masanya dalam bidang Hadits, Rijal al Hadits, Gharib, Matan, Sanad dan juga Pengambilan hukum, dan Imam Suyuthi mengakui bahwa ia hafal 200.000 hadits (al Hasan, 2000: 282). Jumlah yang sangat fantastis dan tidak semua orang sanggup melakukan seperti yang sudah dilakukan oleh Imam Suyuthi ini.

Selain itu, Imam Suyuthi merupakan ulama yang produktif dalam menulis 
karya-karya ilmiah dalam berbagai disiplin ilmu pengetahuan, seperti Tafsir, Hadits, Fiqh, Nahwu, Maani, Bayan, Badi, Ushul Fiqh, al Jadal, at Tashrif, al Insya, at Tarassul dan al Faraidh (Muhaisin, 1992: 126). Karya-karya Imam Suyuthi dalam berbagai disiplin ilmu diatas terdokumentasikan dalam bentuk buku yang hampir mencapai tiga ratus judul buku dalam berbagai disiplin ilmu, yang dimulai penulisannya sejak tahun $866 \mathrm{H}$.

Menjelang akhir hayatnya, Imam Suyuthi meninggalkan keramaian dan majlis ilmu dalam bidang pengajaran dan karya ilmiah. Imam Suyuthi memilih untuk fokus beribadah. Setelah melalui keh panjang dalam kehididupan yang panjang dan sibuk dengan ilmu dan keilmuan serta pengetahuan serta praktik belajar-mengajar dalam format halaqah dan juga majlis al-ilmi, Imam Suyuthi kemudian wafat pada hari Kamis 9 Jumadil Ula tahun $911 \mathrm{H}$ dan dimakamkan di kota Kairo disuatu pemakaman yang dikenal sekarang dengan nama "Pintu Gerbang Sayyidah Aisyah" (as Suyuthi, tt: 37).

2. Metodologi Penulisan ad Dar al-Mantsur fi at Tafsir bi al Matsur

Ad Dar al-Mantsur fi at Tafsir bi al Matsur karya Imam Suyuthi merupakan kitab tafsir yang dikategorikan sebagai kitab tafsir al Ma'tsur. Kitab ini merupakan ringkasan dari karya tulisnya yang berjudul "Tarjaman al Quran", suatu kitab tafsir yang metodologi penafsirannya berdasarkan al Quran, Hadits Nabi SAW, Penafsiran Shahabat dan juga Tabiin (Abu Shahbah, tt: 124). Kitab tafsir ini memerlukan investigasi takhrij hadits dan juga memerlukan fihris. Kelebihan kitab tafsir ini seperti pemakaian metodologi matsur, sedangkan kekurangan-kekurangan yang paling krusial seperti tidak adanya sanad yang utuh (al Rumi, 2003: 158). Sanad merupakan unsur yang sangat penting dalam validasi shahih tidaknya suatu hadits maupun atsar. Berbeda dengan tafsir Thabari yang mencantumkan sanad dan riwayat hadits maupun atsar secara sempurna. Berikut ini adalah Metodologi yang peneliti hasilkan, yaitu :

Pertama Metodologi Matsur. Metodologi matsur merupakan metodologi dominan yang ditemukan dalam kitab tafsir ini. Akan tetapi, menafsirkan al Quran dengan al Quran merupakan hal yang sulit ditemukan dikarenakan metodologi mayoritas didalam kitab ini adalah menafsirkan al Quran dengan Hadits, Pendapat Shahabat dan juga Tabiin, yang dikutip dari kitabnya Imam Thabari, sehingga dapat disimpulkan bahwa kitab Suyuthi ini juga merupakan ringkasan dari kitabnya Thabari, namun tanpa pencantuman sanad secara sempurna. Walaupun demikian, Imam Suyuthi tetap menggunakan metodologi penafsiran al Quran dengan al Quran seperti dalam menafsirkan surat al Anfal ayat 5-6 (as Suyuthi, 14). Dalam menafsirkan al Quran dengan 
hadits, as Suyuthi mengutip hadits-hadits yang dikategorikan Shahih, Hasan maupun Dhoif sebagai argumentasi tanpa penjelasan ke-validan haditshadits tersebut. Penulis tidak mencantumkan kutipan-kutipan contoh penafsirkan metodologi matsur yang dimuat dalam kitabnya as-Suyuthi ini dikarenakan penulis sudah mencantumkan dalam metodologi as Syinqithi. Akan tetapi penulis mencantumkan metodologi tambahan yang dimuat as Suyuthi, seperti:

Kedua Referensi dari kitab-kitab Tafsir, Hadits dan Ulum al Quran sebagai Sumber Primer. Imam Suyuthi dalam menafsirkan ayat-ayat al Quran mengutip Hadits dan Atsar yang terdapat dalam kitab-kitab yang beragam, seperti Tafsir, Hadits dan Ulum al Quran tanpa dibarengi dengan penyebutan sanad, dan itu banyak ditemukan didalam kitab tafsirnya. Contohnya dalam menafsirkan surat al Baqarah ayat 24 (as Suyuthi, 67-91). Dalam menafsirkan ayat diatas, Imam Suyuthi mengutip Hadits dan Atsar dari berbagai kitab sebagai sumber primer, yaitu: Ahmad bin Hanbal dengan kitab Musnadnya, Bukhari dan Muslim dengan kitab shahihnya, Abu Daud dengan sunannya, Ibnu Majah dengan sunannya, an-Nasai dengan sunannya, al Baihaqi dengan sunannya, Ibnu Abi Syaibah dengan kitab Mushonnafnya, Abd Rozzaq dengan sunannya merupakan kitab-kitab Hadits dan juga Atsar. Sedangkan Ibnu Jarir dikenal dengan kitabnya Jami al Bayan fi Tawil Ay al Quran yang merupakan kitab tafsir. dan Ibnu adh Dhoris dengan Fadhoil al Qurannya merupakan kitab Ulum al Quran.

Ketiga Tidak adanya Validasi antara Pendapat Shahabat dan Tabiin. Hasil yang utama dari kajian metodologi tafsirnya as Suyuthi adalah tidak adanya validasi kualitas Hadits sebagai sumber penafsiran pendukung, dan ini hampir ditemukan didalam kitab ini dari halaman pertama sampai dengan halaman terakhir. Satu contoh saja dalam menafsirkan surat al Imran ayat 144 (as Suyuthi, 334-336). As Suyuthi dalam menafsirkan ayat tersebut dengan mengacu ke beberapa Hadits dan Atsar. Bisa diperhatikan bahwa Imam Suyuthi hanya mengutip dan memasukkannya kedalam bab-bab yang sesuai dengan topik ayat yang hendak ditafsirkan tanpa memvalidasi apakah hadits dan atsar tersebut Shahih, Hasan, Dhoif atau validasi sanad yang lain seperti maqtu dan maudu. Hal ini sesuai dengan tujuan semula dari penulisan kitab ini yang telah dijelaskan oleh Imam Suyuthi dalam muqaddimahnya yaitu "mempermudah pembaca tanpa susah untuk membaca rawi maupun klassifikasi Shahih, Hasan atau Dhoif". 
Hanya seperti inilah metodologi penafsiran Imam Suyuthi dalam tafsirnya, metodologi yang tidak terlalu beragam dan cenderung hanya menyajikan seputar informasi penafsiran yang ada, tanpa melakukan validasi terhadap riwayat sanad maupun matan.

\section{Simpulan}

Kitab-kitab Tafsir ditinjau dari sisi Metodologi yang paling mendekati pengertian al Matsur adalah Adhwa al Bayan fi Iydhah al Quran bi al Quran karya asy Syinqithi, diikuti dengan Jami al Bayan fi Tawil al Quran karyanya Imam Ibnu Jarir al Thabari. Tafsir al Quran al Adzhim karyanya Ibnu Katsir dan disusul al Dar al Mantsur fi at Tafsir bi al Matsur karyanya Imam Suyuthi. Selain kitab-kitab tersebut, masih banyak kitab-kitab yang diklassifikasi sebagai Tafsir bi al Matsur, seperti Bahru al Ulum karya Abu al Laits as Samarqandi dan Irsyad al Aqli as Salim karya Abu as Suud.

Apabila berpegang kepada Defenisi al Matsur maka kitab yang paling mutamad dan valid adalah Adhwa al Bayan fi Iydhah al Quran bi al Quran. Apabila berpegang kepada kitab yang paling turats dan senioritas penulis, maka kitab yang paling mutamad dan valid adalah Jami al Bayan fi Tawil al Quran. Tafsir al Quran al Adzhim merupakan ringkasan dari kitab Jami al Bayan fi Tawil al Quran, sehingga menempati posisi ketiga. Peringkat keempat adalah kitab al Dar al Mantsur fi at Tafsir bi al Matsur dikarenakan validasi sanad yang hanya mencantumkan rawi yang paling dekat.

\section{Daftar Pustaka}

Al Qaththan, Manna bin Kholil. 2000. Mabahits fi Ulum al Quran. Beirut: Maktabah al Maarif.

Adz Dzahaby, Muhammad Husain. Tt. At Tafsir wa al Mufassirun. Kairo: Maktabah Wahbah.

As Suyuthi, Abd Rahman bin Abi Bakr. 1394 H/1974 M. Al Itqan fi Ulum al Quran. Kairo: al Haiah al Ammah al Mishriyah.

Al Haji, Muhammad Umar. 1427 H /2007 M. Mausuah at Tafsir Qabla Ahdi at Tadwin. Beirut: Dar al Maktabi.

Al Rumi, Fahd bin Abd Rahman bin Sulaiman. 2003 M/1424 H. Dirasat fi Ulum al Quran. 
As Syinqithi, Muhammad al Amin bin Muhammad al Mukhtar. 1415 H/1995 M. Adhwa al-Bayan fi Iydhah al Quran bi al Quran. Beirut: Dar al Fikri.

Ath Thabari, Muhammad bin Jarir. 1420 H/ 2000 M. Jami al Bayan fi Tawil al Quran, Beirut: Muasasah ar Risalah.

Ibnu Katsir, Ismail bin Umar. 1988. Al Bidayah wa an Nihayah. Tahqiq: Ali Syirry, Beirut: Dar Ihya at Turats al Araby.

As Suyuthi, Abd Rahman bin Abi Bakr. Tt. Ad Dar al Mantsur fi at Tafsir bi al Matsur, Beirut: Dar al Fikr.

Al Khurasani, Said bin Manshur bin Syubah 1997 M/1417 H. At Tafsir min as Sunan Said bin Manshu. Dar al Shami.

As Syafi'i, Muhammad bin Idris. 1370 H/1951 M. Musnad al Imam as Syafi'i. Beirut: Dar al-Kutub al Ilmia.

As Suyuthi, Abd Rahman bin Abi Bakr. 1394 H/1974 M. Al Itqan fi Ulum al Quran. Kairo: al Haiah al Ammah al Mishriyah.

Al Haji, Muhammad Umar. 1427 H /2007 M. Mausuah at Tafsir Qabla Ahdi at Tadwin. Beirut: Dar al Maktabi.

Adz Zarqani, Muhammad Abd al Adzim. 1367 H. Manahil al Irfan fi Ulum al Quran. Kairo: Isa Bab al Halaby.

Nasir, Sholihun A. 2010. Pemikiran Kalam (Teologi Islam): Sejarah, Ajaran, dan Perkembangannya. Jakarta: Rajawali Pers.

Athiyah, bin Muhammad Salim. 1974. Maa Shohib al Fadhilat Walidna asy Syaikh Muhammad Amin asy Syinqithi. Madinah: Jamiah al Islamiah.

Ibnu Khalkan, Ahmad bin Muhammad bin Ibrahim. Tt. Wafyat al Ayan wa Anba Abna az Zaman. Beirut: Dar ash Shodir.

Az Zirikly, Khoir ad Din bin Mahmid bin Muhammad Bin Ali. 2002. al A'lam. Beirut: Dar al Ilmi li al Malayin.

Al Hamawi, Shihabuddin Yaqut bin Abdillah. 1993. Mujam al Udaba. Beirut: Dar al Gharbi al Islami.

Muhaisin, Muhammad bin Muhammad bin Muhammad Salim. 1992. Mujam Huffazh al Quran Ibr at Tarikh. Beirut: Dar al Jail. 
Al Hasan, Muhammad Ali. 2000 M/ 1421 H. al Manar fi Ulum al Quran Maa Madkhal fi Ushul at Tafsir wa Mashadiruhu. Beirut: Muassasah al Risalah.

Al Mazzi, Yusuf bin Abd Rahman bin Yusuf. 1417 H. Tahdzib al Kamal fi asma al Rijal. Beirut: Muassasah ar Risalah.

Al Husaini, Syamsuddin Muhammad bin Ali bin al Hasan bin Hamzah. 1998 M. Dzail Tadzkirah al Huffazh. Beirut: Dar al Kutub al Ilmiah.

Ibnu Katsir, Muhammad bin Katsir. 1416 H. Fadhail al Quran. Damaskus: Maktabah Ibn Taimiyah.

Azh Zhahiri, Yusuf bin Tagri Bardi bin Abdillah. Tt. Al Mihal ash Shofi wa al Mustaufa bada al Wafi. Kairo: al Haiah al Mishriyyah al Ammah li al Kitab.

Taqiyuddin, Muhammad bin Ahmad bin Ali. 1990. Dzai at Taqyiid fi Ruwat as Sunan wa al Asanid. Beirut: Dar al Kutub al Ilmiah.

As Suyuthi, Jalal ad Din Abd ar Rahman bin Abi Bakr. Tt. Dzail Thabaqat al Huffaz. Beirut: Dar al Kutub al Ilmiah.

Abu Shahbah, Muhammad bin Muhammad bin Suwailim. Tt. Al Israiliyat wa al Maudhuat fi Kutub at Tafsir. Kairo: Maktabah as Sunnah.

Al Baihaqi, Dzohir ad Din Ali bin Zaid bin Muhammad. 1425 H. Tarikh Baihaq. Damaskus: Dar Iqra.

Al Bigha, Musthofa Diib. 1998 M. al Wadhih fi Ulum al Quran. Dar al Kalam ath Thoib/Dar al Ulum al Insaniyah.

Al Utsaimin, Muhammad bin Shalih bin Utsaimin. 1995 M/1415 H. Syarah Muqaddimah at-Tafsir Li Ibn Taimiah. Riyadh: Dar al Wathan.

As Suyuthi, Jalal ed Din, Abd Rahman bin Abi Bakr. Tt. Asrar Tartib al Quran. Kairo: Dar al Fadhilah. 